\title{
RELATO ENMARCADO Y RELATO MARAVILLOSO EN LA CASA TRISTE (SOFÍA CARRILLO, 2013)
}

Frame Story and Folktale in the Animated Short Film: La casa triste (Sofia Carrillo, 2013)

Carmen Vitaliana Vidaurre-Arenas ${ }^{\mathrm{a}}$

Universidad de Guadalajara (Jalisco, México)

DOI: 10.15366/secuencias2018.48.004

\begin{abstract}
RESUMEN
En este artículo estudiamos, a partir de algunas propuestas de Propp, Kayser, Genette y Aumont, el cortometraje de animación La casa triste (Sofía Carillo, 2013), en el que se presenta una modalidad específica del relato metadiegético y del relato maravilloso.

José Burguera señala que este tipo de filmes permiten explorar inquietudes que no encuentran expresión en la formalización racionalista del pensamiento actual. A esto se suma que el análisis permite identificar una variación del relato enmarcado mediante la cual se interpretan míticamente acontecimientos históricos que figuran en el filme y que hacen evidentes ideologías dominantes en el contexto de producción del corto.
\end{abstract}

Palabras clave: Relato metadiegético, relato maravilloso, stop motion, cine mexicano, Sofía Carrillo, La casa triste

\section{ABSTRACT}

In this article, we study, through some of Propp, Kayser, Genette and Aumont's proposals, the animated short film La casa triste (Sofia Carrillo, 2013), which presents a specific modality of the metadiegetic narrative and the fantasy tale. We agree with José Burguera when he points out that the proliferation of this type of films allows us to explore concerns that do not find expression in the rationalization of current though. Thus, our study allows us to identify a structural variation of the framed story according to which the historical events that appear in the film - and that portray the dominant ideologies of the time - are mythologically interpreted.

Keywords: Metadiegetic narrative, folktale, stop motion, Sofia Carrillo, Mexican film, La casa triste

[a] Carmen Vitaliana Vidaurre-Arenas es profesora-investigadora del Departamento de Artes Visuales del Centro Universitario de Arte, Arquitectura y Diseño de la Universidad de Guadalajara (Jalisco, México), donde imparte cursos en posgrado y en las licenciaturas en Artes Visuales. Es miembro del Sistema Nacional de Investigadores desde hace 25 años. Fue integrante del Consejo Estatal para la Cultura y las Artes de Jalisco, por dos periodos consecutivos. Es miembro de la Comisión Evaluadora de Revistas Científicas Nacionales para CONACYT desde hace 7 años. Fue cofundadora del Doctorado en Arte y Cultura del CUAAD (clasificado como de excelencia por CONACYT). Es autora de más 20 libros publicados en editoriales académicas nacionales e internacionales y de numerosos artículos especializados. Realizó sus estudios doctorales en la Universidad «Paul Valéry» (Montpellier, Francia). E-mail: maga2315@hotmail.com 


\section{Introducción}

En las últimas décadas, el cine de animación ha cobrado particular importancia en México y no solo por el número de realizadores que lo cultivan ${ }^{1}$, también por los reconocimientos nacionales e internacionales recibidos. Esta importancia también se manifiesta en el interés por su estudio historiográfico, que puede ejemplificarse con la publicación de dos obras especializadas, el trabajo de Juan Manuel Aurrecoechea ${ }^{2}$ y el de Manuel Rodríguez Bermúdez ${ }^{3}$, precedidas y continuadas por diversas tesis doctorales sobre realizadores y obras, ensayos panorámicos y otros estudios. Como fenómeno social, este no carece de antecedentes y en su verificación confluyen múltiples factores, algunos señalados por estudiosos que han observado también los altibajos y problemáticas involucradas en el proceso histórico de la animación en México.

Aurrecoechea destaca el papel que, en el auge de la animación en el país, desempeñó el reconocimiento internacional con que fue distinguido un cortometraje mexicano realizado con la técnica de pintura sobre cristal:

A este repunte se asocia simbólicamente el triunfo de El héroe, la expresionista y pesimista fantasía urbana de Carlos Carrera, que obtuvo la Palma de Oro en el Festival de Cannes de 1994 [...], la primera de una copiosa producción de cintas [...] que han permitido surgir y florecer a una talentosa generación de animadores que ya han dado pruebas de calidad, obteniendo un sinnúmero de premios en los festivales internacionales ${ }^{4}$.

Este cortometraje ${ }^{5}$, cuya estética podríamos calificar como neoexpresionista, ha sido objeto de varios análisis, el más importante de la académica y realizadora de animación Cecilia Navarro ${ }^{6}$. Aunque este corto aborda una problemática social, un notable número de producciones - muchas de ellas dirigidas a públicos adultos y desarrolladas con las más diversas técnicas de animación-, permite identificar que, pese a la variedad temática, ciertos asuntos y géneros, entre ellos el llamado «cine fantástico» constituyen constantes en la producción contemporánea.

$\mathrm{Al}$ respecto, Juan Carlos Vargas se ha referido al «macrogénero» fantástico en el cine mexicano:

[1] Se pueden mencionar, entre otros: Dominique Jonard, Guillermo Rendón, Miguel Anaya, Jorge Villalobos, José Luis Rueda, Lourdes Villagómez, Andrea Robles, Adriana Bravo, Eric Beltrán, René Castillo, Luis Téllez, José Ángel García Moreno, Gildardo Santoyo del Castillo, Homero Ramírez Tena, Ulises Guzmán, Rita Basulto, Francisco Javier Jiménez Cabrera, Luis Beltrán, Juan José Medina, Karla Castañeda, Sofía Carrillo, Pedro «Zulú» González, Emilio Ramos, Lucía Gajá, Ana Gabriela Badillo, Rigoberto Mora, Jorge Ramírez, Jaime Cruz, Axel Herreman, Raúl Morales, Pablo Calvillo, Agustín Pablo Álvaro, Ángeles Zuman, Leopoldo Aguilar Guerrero, Guadalupe Sánchez Sosa, Manuel Tonatiuh Moreno Ramos, Miguel Anaya Borja, Mariana Gutiérrez Lascurain Gual, Raúl Cárdenas Rivera, León Fernández, Víctor René Ramírez Madrigal, Lorenza Manrique Mansour, Luis Vázquez, Pablo Ángeles, Mara Soler Guitián, Eduardo B. Gutiérrez Múgica, César Gabriel Cepeda Sánchez, Alexandra Castellanos Solís, Esteban Azuela Suárez, Eduardo Martínez Pichardo, Héctor Dávila Cabrera, etc.

[2] Juan Manuel Aurrecoechea, El episodio perdido. Historia del cine mexicano de animación (México, Cineteca Nacional, 2004).

[3] Manuel Rodríguez Bermúdez, Animación: una perspectiva desde México (México, Centro Universitario de Estudios Cinematográficos de la Universidad Nacional Autónoma de México, 2007)

[4] La Redacción, «El repunte del cine mexicano de animación» («Cultura y Espectáculos», Proceso, 29 de mayo de 2002). Disponible en: <http://www.proceso.com.mx/242212/reportaje-el-repunte-del-cine-mexicano-de-animacion> (2/08/2017)

[5] Carlos Carrera ha realizado seis cortometrajes de animación además de otros trabajos cinematográficos y televisivos. En 2018, codirigió, con Enrique Navarrete, el largometraje animado Ana y Bruno, cuya producción tuvo una duración de cerca de diez años y cuyo costo no logró cubrirse con los ingresos de taquilla obtenidos.

[6] Cecilia Mónica Navarro Herrera, El drama urbano en el cine animado de Carlos Carrera: análisis del cortometraje «El héroe» (Tesis de Maestría inédita, Guadalajara, Universidad de Guadalajara, 2004). 
[7] Juan Carlos Vargas Rodríguez, «Breve panorama del cine fantástico mexicano del nuevo milenio 2000- 2014. Tendencias y rutas temáticas» (Historia $y$ Espacio, $\mathrm{n}^{\circ} 46,2016$ ), p. 223.

[8] José Burguera Rozado, Donación simbólica, donación siniestra: aportaciones sobre el cine de fantasía y el cine fantástico (Tesis Doctoral inédita, Madrid, Universidad Complutense, 2015), p. 11.

[9] Gérard Genette, Figuras III (Barcelona, Lumen, 1989), p. 287-289.

[10] Wolfgang Kayser, Interpretación y análisis de la obra literaria (Madrid, Gredos, 1992), p. 162-168.

[11] Jesús González Requena, Clásico, manierista, postclásico. Los modos del relato en el cine de Hollywood (Valladolid, Castilla Ediciones, 2007).

[12] Vladimir Propp, Morfología del cuento (Madrid, Fundamentos, 1974). Integra también formulaciones de Julien A. Greimas y Lévi-Strauss, sobre los trabajos de Propp, desde la perspectiva de González Requena y aportaciones de este último expuestas en diversos trabajos publicados entre 1995 y 2013, así como algunas consideraciones formuladas por Joseph Campbell y trabajos teóricos sobre el concepto de lo fantástico.

[13] Juan José Burguera, Donación simbólica, donación siniestra: aportaciones sobre el cine de fantasía y el cine fantástico, p. 27.

[14] Jacques Aumont y Michel Marie, Análisis del film (Barcelona, Paidós, 1990), p. 13.
En la revitalización del macrogénero, marcado por un contexto transnacional y global, se distingue un aumento considerable en la producción, [...] por cineastas debutantes que conquistaron un nuevo nicho de mercado y ofrecen [...] una diversidad temática y estilística. A la vez se dio un proceso de legitimación [...] debido al reconocimiento obtenido y al impacto de la obra de ciertos directores, como la de Guillermo del Toro [...]. El fenómeno no es exclusivo de México [...] $]^{7}$.

La importancia del cine «fantástico» en la producción cinematográfica internacional ha llevado a estudios centrados en aspectos más específicos. Así, Juan José Burguera destaca la proliferación de este tipo de obras «desde los inicios del siglo XXI» ${ }^{8}$ y analiza una serie de filmes, Big Fish (Tim Burton, 2003), El laberinto del fauno (Guillermo del Toro, 2006) y La vida de Pi (Life of $\mathrm{Pi}$, Ang Lee, 2012), en los que se emplea la técnica del «relato metadiegético» (Gérard Genette), ${ }^{9}$ también llamado «relato enmarcado» (Wolfgang Kayser) ${ }^{10}$, aplicando propuestas de González Requena (sobre los modos del relato) ${ }^{11}$ y de Vladimir Propp (análisis de la estructura de acciones y funciones) ${ }^{12}$. Según su estudio, en esos filmes la narración-marco correspondería a un contexto realista en el que se introduce: «un relato maravilloso que se despliega en un segundo hilo argumental [...], ambos [...] se entrelazan a lo largo de la narración y [... el] relato maravilloso termina por tener consecuencias para el protagonista en su realidad» ${ }^{13}$.

De una manera distinta, la directora mexicana Sofía Carrillo se vale también del relato enmarcado en uno de sus filmes. Aquí nos proponemos estudiar las estrategias particulares que ella emplea, así como la forma en que recupera algunos de los elementos utilizados en los relatos de tradición oral, identificados con los relatos maravillosos a partir de los estudios de Propp, autoridad en el tema. Aunque partimos de las propuestas del analista ruso, tomamos en cuenta otras más contemporáneas como las de Alicia Mariño, David Roas y Tzvetan Todorov. Sobre el relato metadiegético consideramos a dos destacados especialistas en el tema, Genette y Kayser, y algunas de las herramientas evaluadas por Jacques Aumont y Michel Marie sobre los análisis cinematográficos, con un enfoque que busca «mantener el equilibrio entre la singularidad de los análisis y la preocupación por la reflexión metodológica» ${ }^{14}$. Las obras de Aumont se consideran referente obligado en los trabajos especializados en cine, por sus agudas revisiones a los diversos métodos de estudio del filme y por su propuesta metodológica centrada es la especificidad del cine, de la que aplicamos un número limitado de instrumentos ofreciendo la descripción de elementos visuales, sonoros, técnicos y las relaciones del filme con otras obras. Además, consideramos que toda obra cinematográfica es un producto cultural capaz de vehicular contenidos ideológicos, lo cual resulta importante debido a que, en este cortometraje, el relato del pasado de una familia se entreteje con ciertos acontecimientos históricos y ambos se entremezclan con otros ficticios para ofrecer una interpretación específica tanto de los sucesos que pertenecerían a una memoria 
familiar, como los que forman parte de una memoria cultural nacional, representados y reinterpretados en el filme.

Resulta pertinente citar a Woodside, cuando señala: «si hablamos de cultura, hablaremos de la cotidianeidad de sus representaciones simbólicas a través de distintos productos y medios culturales que refuerzan y/o modifican una memoria cultural latente; es decir, aquella forma de conciencia histórica intersubjetiva que se vive como memoria y no solo como conocimiento sobre el pasado» ${ }^{15}$. Esta observación nos lleva a analizar la particular ideología que sobre el pasado histórico representado se manifiesta en el corto y no solo a reflexionar sobre los fenómenos culturales a los que corresponde la adscripción genérica y las funciones semánticas que los recursos utilizados involucran.

\section{Material y estudio: La casa triste (Sofía Carrillo, 2013)}

Producido por el Fondo Nacional para la Cultura y las Artes y Nahuyaca Films, La casa triste (2013) contó con fotografía de Paola Chaurand, edición de Uri Espinosa Cueto, música de Fernando Arias, Yolihuani Curiel y Sofía Orozco y sonido a cargo de Odin Acosta; la animación, la dirección artística y la dirección del filme fueron de Sofía Carrillo. En este cortometraje a color de 13 minutos se emplea la técnica de animación cuadro por cuadro, en la modalidad de animación de objetos de uso común que algunos investigadores consideran dentro de la denominada pixelación o pixilación (pixilation) ${ }^{16}$ y otros la separan, para limitarla a la animación con «actores» ${ }^{17}$. La animación con objetos tuvo entre sus precursores a Georges Méliès ${ }^{18}$ y Segundo de Chomón ${ }^{19}$. Fue utilizada por Hans Richter, Dziga Vertov, Fernand Léger, Walerian Borowczyk y, posteriormente, por Norman McLaren, Jan Švankmajer, Stephen y Timothy Quay, entre otros célebres realizadores. Esta técnica plantea la representación del movimiento autónomo de objetos que no lo producen por sí mismos, por lo que involucra la producción de lo que algunos teóricos consideran maravilloso en tanto que presenta un «universo» que no responde a las leyes naturales y en el que lo imposible se presenta como posible ${ }^{20}$. Las obras visuales que la emplean son clasificadas dentro del cine fantástico, que suele englobar lo que muchos estudiosos consideran géneros distintos: narraciones fantásticas ${ }^{21}$, maravillosas $^{22}$, feéricas ${ }^{23}$, mitológicas ${ }^{24}$, ciencia ficción ${ }^{25}$, etc.

Los métodos elegidos aquí conceden importancia a la sucesión específica de los elementos constitutivos de la obra y a sus características: en relación
[15] Julián Woodside, «Cine y memoria cultural: la ilusión del multiculturalismo a partir de dos películas mexicanas de animación» (Estudios sobre las Culturas Contemporáneas, $\mathrm{n}^{\circ}$ 36, vol. XVIII, 2012), p. 70.

[16] Miguel Vidal Ortega, Contribución de la animación cinematográfica, el desarrollo del trucaje cinematográfico $y$ los efectos especiales en el cine contemporáneo (Tesis Doctoral inédita, Valencia, Universidad Politécnica de Valencia, 2008) y Abhilasha Bhartiya, «Stop Motion. A Study on the Most Usefull Technique of Experimental Animation" (Shrinkhala, vol. II, 2015), pp. 1-8.

[17] Karina Castro y José Sánchez, Dibujos animados y animación (Quito, CIESPAL, 1999).

[18] La Lune à un mètre (1898), Cendrillon (1899), Les 4oo farces du Diable (1906), Le locataire diabolique (1909), entre otros cortometrajes, sin títulos en español, en los que animó objetos para producir efectos de movimiento autónomo aparente, aunque eran utilerías que imitaban objetos de uso común.

[19] La casa encantada (1907) y El hotel eléctrico (1908). También fue precursor de la animación con modelados de arcilla (El escultor moderno, 1908).

[2o] Tzvatan Todorov, Introducción a la literatura fantástica (México, Premiá, 1987).

[21] David Roas, Tras los límites de lo real. Una definición de lo fantástico (Madrid, Páginas de Espuma, 2001).

[22] Georg Luckás, «Das Problem des untragischen Dramas» (Die Schaubühne, nº 7, 1911), pp. 231-234.

[23] Bruno Bettelheim, Psicoanálisis de los cuentos de hadas (Barcelona, Grijalbo-Mondadori, 1994).

[24] Claude Lévi-Strauss, Mito y Significado (Buenos Aires, Alianza Editorial, 1986).

[25] Noemí Novel Monroy, Literatura y cine de ciencia ficción. Perspectivas teóricas, (Tesis Doctoral inédita, Barcelona, Universitat Autònoma de Barcelona, 2008). 
[26] Aumont destaca las dificultades de segmentación en secuencias y cuadros, por lo que aquí evitamos referirnos a tales términos. Jacques Aumont, Estética del cine. Espacio filmico, montaje, narración, lenguaje (Buenos Aires-Barcelona-México, Paidós, 2008), pp. 60-61.

[27] Jacques Aumont, Estética del cine. Espacio filmico, montaje, narración, lenguaje.

[28] Propp define la función de una acción como el significado que esta adquiere en relación con las que le preceden y le son posteriores dentro de la cadena narrativa. Vladimir Propp, Morfología del cuento.

[29] Denominación utilizada por Jacques Aumont y Michel Marie, Análisis del film, p. 206.

[3o] Jacques Aumont y Michel Marie, Análisis del film, p. 206. con la organización del conjunto de segmentos ${ }^{26}$, encuadres, angulaciones y sonidos ${ }^{27}$ y para establecer el significado de las acciones ${ }^{28}$, por lo que debemos ofrecer una descripción del filme, procurando seguir el orden que este presenta; orden que es solo interrumpido para explicar algunos fenómenos que tienen relevancia para los metodólogos elegidos y para aclarar datos históricos o recursos involucrados en el filme.

El cortometraje inicia con vistas parciales de una ventana en la que hay diversos objetos (sobre el alféizar), que connotan abandono (botellas, cartones arrugados). El encuadre se hace desde el exterior, donde empieza a llover. Estas imágenes han sido precedidas por una panorámica de un cielo nublado y el sonido de truenos de tormenta, que se mezclan con una música repetitiva. Mediante un travelling horizontal, vemos un espacio interior de paredes empapeladas, donde sobre un viejo secreter, de color pastel, hay una muñeca, prendas de ropas infantiles colgadas en un tendedero, que se desplazan como telón para dejar ver una fotografía, con otras sobrepuestas, enmarcada y colgada en la pared. Hay cuadros en los muros laterales y, a ambos lados del secreter -visto en un plano completo frontal-, objetos y muebles.

En el filme se presenta el contexto antes que a los personajes, no se indica una geografía, ni una fecha. Sólo sabemos que es de día, que llueve, que el espacio refiere a lo dañado por el tiempo y el abandono.

En el interior, la lluvia se filtra a través de las grietas del techo, mostradas en plano detalle, mientras se escucha el sonido del agua gotear, se trata de «sonido de pantalla» ${ }^{29}$ (sonido sincrónico). Es decir, que la banda sonora se compone por sonidos diegéticos sincrónicos, pero también por una música que contribuye a crear una atmósfera y cuyo origen no se muestra (sonido asincrónico).

Como observan Aumont y $\mathrm{Marie}^{30}$, al hablar de la función del sonido en el cine, este conlleva diversas funciones simultáneamente, siendo difícil trazar distinciones entre caracterización, explicación y comentario. Los sonidos se producen en este corto, en la mayoría de los casos, en compañía de la imagen, contribuyendo a la descripción, creando efectos de verosimilitud cuando son sonidos concretos cuya fuente se identifica visualmente, pero también se atribuyen a los objetos sonidos que estos no podrían producir aunque se les relacionen semánticamente (un caballo de juguete y el galopar veloz de un caballo, por ejemplo), lo que contribuye a los efectos de lo maravilloso.

El agua cae hasta la cabeza de la muñeca rota (sonido de gotas cayendo), cuyo atuendo se aleja para mostrar que la cabeza no tiene cuerpo; llora lágrimas turbias y se coloca sobre la parte superior del secreter para conformar un ser híbrido: un mueble con cabeza.

Si mediante la animación de objetos se representa la locomoción autónoma de lo inerme, aquí también se crea un ser que participa de rasgos humanos (rostro, cabeza), pese a tratarse de un secreter, y que realiza acciones análogas a las vitales (moverse, llorar) y posee capacidades telequinéticas, rasgo sobrenatural derivado de que cuando la cabeza se inclina, como mirando hacia el cajón central 
del mueble que es su cuerpo, este se abre (produciendo un sonido apagado) y en el interior del cajón podemos ver un brazo con su mano, que podría ser de la muñeca (por sus dimensiones y aspecto). La existencia de este personaje no responde a una explicación «racional». Se le atribuyen capacidades paranormales y se «abre» mostrando lo que guarda: su brazo, una revista, una llave, dos bolígrafos y un libro. El brazo se mueve, abre el libro, visto en plano detalle, en el que hay el dibujo de un ave, en otra página el dibujo de un rostro infantil - semejante a una luna llena con sombrero alargado- y, en la siguiente, el título del cortometraje en cursivas. El pequeño brazo pasa la página (sonido del papel), vemos el retrato dibujado de un hombre y, en la página contigua, el dibujo de una enredadera.

La situación planteada se refiere a un pasado «atemporal», en un lugar impreciso, caracterizado como un «viejo desván» de la memoria: una casa abandonada y llena de vestigios del pasado donde un personaje fantástico va a mostrarnos una historia contenida en un libro de memorias que guarda.

En el filme domina la ausencia de convenciones realistas, pues en otro encuadre completo de la muñeca-secreter observaremos que su cabeza gira hacia el lugar donde hay una lámpara fijada sobre un muro lateral, y la lámpara se enciende, la cabeza vuelve a inclinarse hacia adelante, y la tapa del secreter baja, permitiendo ver diversos cajones, papeles y objetos, entre ellos un alfiletero con forma de muñeca. Los cajones y objetos se animan, produciendo ruidos, se muestra en detalle el alfiletero-muñeca al que se aproxima un pequeño y deteriorado perro de felpa, para luego introducir otros dos personajes: un pequeño caballo y una figura masculina de cerámica, que se mueve (produciendo ruido de arrastre al «desplazarse») y se coloca frente al alfiletero.

Hasta ahora, se ha estado utilizando un sistema de diadas para introducir a los personajes: un ave y un rostro infantil, un hombre y una enredadera, un alfiletero-muñeca y un perro de felpa, un hombre de cerámica y un caballo y la muñeca-secreter, estructurada por una «diada» de objetos (muñeca-mueble).

A lo anterior se añade que los elementos iconográficos de las citadas imágenes, y de otras posteriores, remiten a destacados filmes de animación a los que el corto rinde homenajes velados porque, pese a las diferencias, el sonido del trueno, el deterioro de los objetos, los cartones arrugados, la tela, una lámpara que se enciende, el cuadro con fotografías, la muñeca y el libro abierto refieren al cortometraje animado Renaissance (Walerian Borowczyk, 1964). Las prendas de ropa animadas, la imagen de un rostro redondo ${ }^{31}$ (en relación con el título del filme), la ventana, la habitación de paredes empapeladas, los frascos, el caballito, un mueble que se abre, la enredadera vegetal y el retrato de un hombre, así como las tachaduras luego dibujadas sobre fotografías remiten a Jabberwocky (Jan Švankmajer, 1971); mientras que la cabeza de la muñeca, los alfileres, las agujas del alfiletero y ciertos elementos macabros y deteriorados aluden a una iconografía recurrente en obras de los hermanos Quay ${ }^{2}$. Estos elementos cumplen con funciones distintas a las que desempeñan en las obras precedentes, pero contribuyen a producir una estética similar y hacen visibles las obras utilizadas como modelo.
[31] Un rostro infantil semejante a una luna en el cortometraje de Sofía Carrillo y un sol con rostro en el de Jan Švankmajer.

[32] El gabinete de Jan Svankmajer (The Cabinet of Jan Svankmajer, Stephen y Timothy Quay, 1984) y La calle de los cocodrilos (Street of Cocodriles, Stephen y Timothy Quay 1986). 


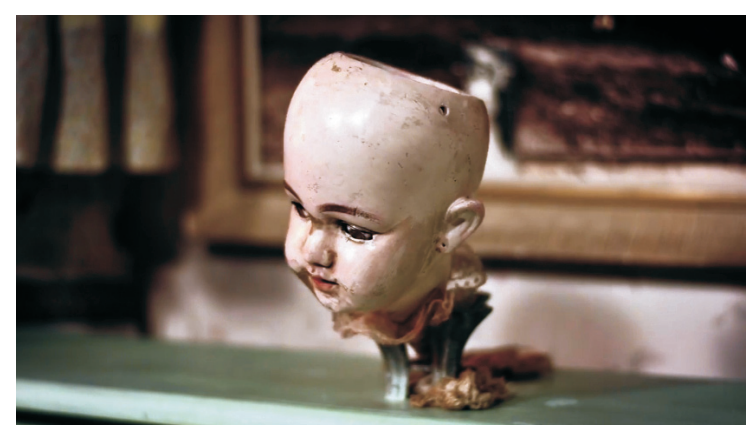

Fotograma de La casa triste (Sofía Carrillo, 2013).

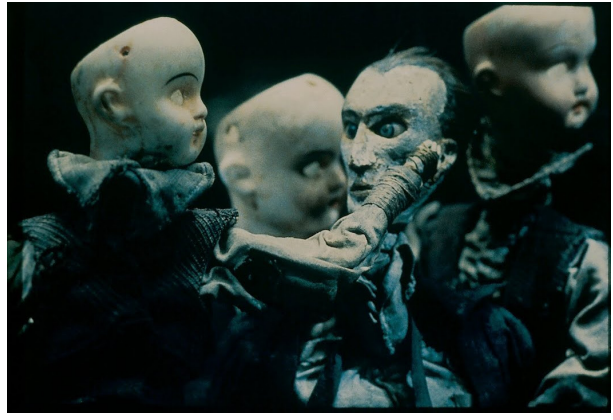

Fotograma de Street of Crocodiles (Timothy Quay y Stephen Quay, 1986).
[33] Vladimir Propp, Morfología del cuento, p. 39.

[34] William Shakespeare, The Tragedy of Hamlet, Prince of Denmark (Hamlet, c. 1560).

[35] Hans Christian Andersen, Den standhaftige Tinsoldat ( $E l$ soldadito de plomo, 1838).

[36] Es importante destacar que no todos los casos de animación de objetos involucran su humanización: puede ocurrir que sigan comportándose como objetos con movimiento autónomo o adquieran comportamientos animales, por ejemplo.
En otro plano detalle, volvemos a ver el libro abierto, sobre cuyas páginas el brazo de la muñeca se desplaza sobre lo escrito: «1927. Hace mucho tiempo, la abuela, siendo huérfana, conoció al abuelo, que también lo era. El día que se casaron, las estrellas bajaron y bailaron con ellos», acontecimiento que se ilustra mediante el plano detalle de una campana de papel que gira (escuchamos el sonido de una caja musical, al que se suman otros que crean un ritmo acelerado y que acompañan a diversos personajes, aunque se trata de sonidos que no podrían ser producidos por las figuras que vemos). La muñeca-alfiletero y la figura masculina de cerámica, colocadas frente a frente, empiezan a girar, imitando una ronda, al mismo tiempo que se van incorporando otros objetospersonajes y las figuras son iluminadas por círculos de luz, en un ambiente nocturno, vistos casi cenitalmente, con un tipo de angulación identificada con «la mirada de Dios» por ofrecer una visión desde lo alto. Estamos ante la situación inicial que caracteriza los relatos maravillosos: «imagen de una felicidad particular, a veces subrayada con especial énfasis» ${ }^{33}$.

El final de la fiesta de boda se indica mostrando en plano medio a uno de los personajes - un sapo disecado que sostiene un papel doblado como un músico de pie con acordeón- que se retira hacia el último plano.

Mediante esta suerte de teatro de objetos, se escenifica un pasado idealizado poéticamente, recuperando recursos utilizados por William Shakespeare ${ }^{34} \mathrm{y}$ Hans Christian Andersen ${ }^{35}$ al incluir la representación dentro de una representación y al humanizar a los objetos protagonistas de la historia ${ }^{36}$.

En otro travelling horizontal de derecha a izquierda (respecto al espectador) se mostrará la figura de cerámica y el alfiletero-muñeca que ahora carga un niño de tela. Al lado de ellos pasa una camioneta de juguete, que antes vimos arrancar en el último plano, y con otro travelling horizontal (en dirección inversa) se muestra en detalle una de las fotografías sobrepuestas en el cuadro en la pared: una pareja de recién casados, debajo de la cual aparecen las fotografías de otro hombre y otra mujer (estas dos últimas en formato 

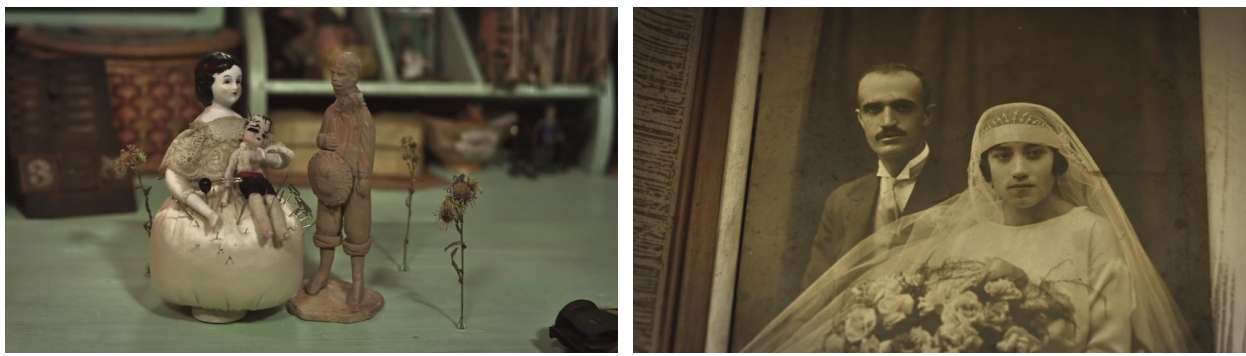

Fotogramas de La casa triste.

credencial), abajo de ellas está la fotografía recortada de otra pareja recién casada. Imágenes que no solo se disponen como un árbol genealógico, también quedan sobrepuestas a la fotografía mayor que sirve de fondo, donde hay una niña de pie en un bosque, figura que queda colocada arriba y detrás de la cabeza de la muñeca-secreter.

El receptor puede inferir que se le está relatando la historia de la pareja de la primera fotografía, que forma parte de una familia. El escrito cumple una función explicativa, indica la identidad de los protagonistas, sus circunstancias, contribuye a precisar algunos de sus rasgos, pues, gracias a él, se sabe que el alfiletero-muñeca representa a la abuela y la figura de cerámica al abuelo, cuya historia es dada a conocer por el personaje secreter al mostrarnos el libro de notas en el que, quien ha escrito, se identifica como descendiente de los protagonistas. El personaje muestra también la escenificación de la historia, al convertirse en el teatrino en el que los objetos representarán el pasado familiar.

Se ha dado inicio así a un relato retrospectivo enmarcado, narrado a través de la palabra escrita y de la escenificación de objetos que hacen el papel de los personajes fotografiados. En el escrito se adoptan elementos retóricos del cuento de tradición oral y de la crónica, pues se ofrece una fecha, 1927, al mismo tiempo que se recupera la frase: «Hace mucho tiempo...», mezclando el dato cronológico y la retórica de la fábula. Por ello, podemos decir que en el contexto marco del relato maravilloso, y en el enmarcado, también maravilloso, se introducen algunos elementos históricos (el dato cronológico y las fotografías), pues, aunque las fotografías se refieran a personajes de cuya existencia dan «testimonio», relato marco y enmarcado son narraciones maravillosas: en ellas encontramos un narrador mudo ficcionalizado y fantástico (la muñeca-secreter), los objetos representan a personas y se verifica lo que no responde a las leyes objetivas de la racionalidad, los objetos están animados, como en los relatos maravillosos:

En un relato maravilloso [...], tanto el lector como el personaje principal se 
[37] Alicia Mariño, «Entre lo posible y lo imposible: el relato fantástico», en Teresa López Pellisa y Fernando Ángel Moreno Serrano (eds.) (Madrid, Asociación Cultural Xatafi-Universidad Carlos III de Madrid, 2009). Ensayos sobre ciencia ficción y literatura fantástica: actas del Primer Congreso Internacional de literatura fantástica y ciencia ficción, pp. 45-46.

[38] Wolfgang Kayser, Interpretación y análisis de la obra literaria, p. 262, 264, 268.

[39] La técnica del relato enmarcado también puede involucrar anticipaciones. Wolfgang Kayser, Interpretación y análisis de la obra literaria, p. 268. sumergen en un mundo regido por normas que nada tienen que ver con la racionalidad [...], con la realidad objetiva. Se trata, pues, de un universo en el que todo es posible, incluso el milagro; de un mundo en el que cualquier acontecimiento, extraño o sobrenatural, nunca es considerado imposible $[\ldots]^{37}$.

Kayser, al estudiar el relato metadiegético, observa que el relato enmarcado constituye un «recurso técnico [...] para satisfacer una exigencia primordial que el lector reclama del arte narrativo: la confirmación de lo narrado», lo cual denuncia la intención de convencer al receptor de la veracidad del relato. Además, destaca que las anticipaciones «[...] dan al lector plena certeza de que el mundo [...] no es amorfo ni difuso [...]» y que en el relato enmarcado, en el que tiene lugar «un hallazgo de papeles o el descubrimiento de documentos [...]», busca también persuadir al receptor de la autenticidad de lo narrado, a lo que contribuye narrar en primera persona, porque, según Kayser: «robustece la impresión de autenticidad» ${ }^{3}$. En el cortometraje se emplea el relato enmarcado y el relato escrito anticipa ${ }^{39}$ que los personajes tendrán un descendiente que escribirá su historia, guardada en el libro guardado. Por esto podemos decir que la estrategia comunicativa utilizada en el filme busca producir la certeza de que esa narración maravillosa - presentada como memoria familiar - es veraz y acorde con una configuración ordenada del mundo. Notaremos también que el relato escrito está en primera persona y ofrece una coordenada temporal con la que estamos familiarizados, un año; pero también manifiesta un estilo poético (refiere que las estrellas bajan del cielo y bailan con la pareja el día de su boda) que aleja la narración del realismo y enfatiza la felicidad de la pareja, humanizando las estrellas, de manera similar a como se humanizan los objetos en el corto, indicios de que lo que se narra sigue correspondiendo a un relato maravilloso.

$\mathrm{Al}$ analizar la breve historia de los abuelos, identificamos que involucra una tácita necesidad de satisfacer una carencia (ambos eran huérfanos), satisfecha al formar una familia. Su historia, aunque presentada en forma sintética, corresponde a la del héroe buscador de Propp, quien debe satisfacer una carencia o reparar un daño.

Esa historia será seguida por otra, introducida igualmente por el escrito, mediante otra fecha y precedida por dos refranes populares: «1928. No hay mal que dure cien años. Al que escupe al cielo, le cae en la cara»; y continuada con datos que aluden a acontecimientos históricos: «En los Altos, allá en el campo, el Estado clausura la iglesia, al pueblo se le priva de los sacramentos, unos combaten, otros son enviados a las concentraciones, ahí se conocen mis otros abuelos».

La referencia a las Guerras Cristeras - conflictos entre el gobierno mexicano y el clero, verificadas durante la presidencia de Calles, entre 1924 y 1928resulta significativa por varias razones: exige cierto conocimiento de la historia del país, introduce elementos retóricos de la crónica e implica un enfoque desde el cual se refieren los hechos reales que consiste en una perspectiva popular 
y no académica, pues la alusión es precedida por dos refranes, uno de ellos sobre la duración de un «mal» y, el otro, con una advertencia a quien ofende al cielo, interpretando así, mediante la voz del refranero, las posturas de los dos bandos del conflicto histórico. En este contexto, el primer refrán aludiría al final del poder intocable del clero (identificado con un mal) y el segundo advertiría a quienes lucharon contra el clero (identificado con el «cielo», al que se escupe). Se ofrece también una ubicación geográfica: «los Altos», y sabemos que Los Altos de Michoacán y Jalisco fueron escenarios del combate y que en Jalisco tuvo lugar «la adscripción casi unánime de los pueblos de Los Altos al bando cristero» ${ }^{40}$.

A diferencia del relato de los otros abuelos, este nos ubica en un lugar concreto del país: se presenta como relato histórico procedente de una memoria familiar y de una memoria colectiva, por lo que se vuelve importante analizar la veracidad con la que se representa.

Respecto a la referencia a la clausura de la iglesia por parte del Estado y la privación de los sacramentos, se debe aclarar que los historiadores señalan siempre que el gobierno no clausuró la iglesia, sino que fue el propio clero, antes del inicio de la aplicación de las leyes, quien, en protesta, privó a la población de los sacramentos ${ }^{41}$. Esto no se aclara en el filme, al identificar al Estado como quien clausura la iglesia y al dejar suponer que es este quien priva al pueblo de los sacramentos, por lo que se percibe la adopción de una perspectiva específica frente a los acontecimientos.

Por otra parte, la referencia a «concentraciones» es un dato que registran los historiadores ${ }^{42}$ y que contribuye a una perspectiva crítica católica frente al gobierno de Calles, pues tales «concentraciones», aunque muy distintas de las verificadas durante la Segunda Guerra Mundial o las de la migración a Francia durante la guerra civil española, manifestaron también una política de imposición y exclusión estratégica.

Estos datos escritos son caracterizados y comentados por la música, creando un ambiente solemne que anticipa las escenas que se mostrarán y en las que se introducen personajes que representan a la segunda pareja de abuelos en su juventud, en el escenario montado sobre el secreter que connota ahora la vida del campo por la presencia de flores y tallos marchitos entre los que se desplazan dos figuras que llevan atuendos propios de actividades agrícolas.

Estas imágenes ilustran lo que el texto ha referido, por lo que tendríamos que señalar la subordinación de las imágenes a las palabras. Las imágenes, sin embargo, no se limitan a repetir lo que las palabras exponen: ofrecen detalles, complementan y narran por sí mismas, ofreciendo el punto de vista desde el cual se relata el conflicto que constituye el contexto histórico de este relato maravilloso de otra pareja, un campo marchito donde ocurre un combate. Se mostrarán en un plano medio las figuras de soldados de plomo en fila y desplazamiento, de derecha a izquierda (de acuerdo al espectador), mientras se escucha la marcha de pasos que indican el avance de grupos de soldados. En otro plano medio se verá la figura masculina que representa al abuelo cubriéndose [4o] Damián López, «La guerra cristera (México, 19261929). Una aproximación historiográfica» (Historiografías, $\mathrm{n}^{\circ}$ 1, 2011), p. 44.

[41] El gobierno criminalizó a quienes se negaron a cumplir las leyes aprobadas por las cámaras, que prohibían: oficiar actos de culto sin ser mexicano, enseñar religión en escuelas primarias, que los ministros religiosos abrieran escuelas, comentar asuntos políticos en la prensa religiosa, realizar actos religiosos fuera del templo y usar fuera del templo hábito religioso o sotana. Los encarcelamientos ocasionaron que algunos templos no abrieran. Con autorización del papa Pio XI, los obispos mexicanos acordaron la suspensión de actos de culto, anunciada al pueblo con una Carta Pastoral Colectiva, que se firmó el 25 de julio de 1926, cinco días antes de que entrara en vigor la llamada «Ley Calles». Damián López, «La guerra cristera (México, 1926-1929). Una aproximación historiográfica».

[42] Jean Meyer, La cristiada. La guerra de los cristeros, (México, Siglo XXI, 1973). Las atrocidades fueron cometidas por ambos bandos y aún es difícil evaluar objetivamente este aspecto de la lucha civil, llamada guerra por involucrar en lo político al Papado. 
los ojos con las manos, mientras delante de él se desplazan, desenfocados, otro grupo de soldados de plomo. Se hará luego un travelling horizontal en el que se muestra una panorámica del escenario: flores y ramas secas, cruces formadas con ramas y diminutas figuras antropomorfas colgadas de tallos secos que representan tumbas y muertos, luego un pequeño jinete en compañía de un caballo sin jinete que cruzan velozmente en dirección opuesta a los soldados. Se trata de una de las pocas tomas con profundidad de campo, pues en la mayoría de las imágenes se usan planos próximos, por tratarse de pequeños objetos, y de escasa profundidad, creando un efecto de proximidad.

La escenificación manifiesta el uso de recursos de síntesis, analogías visuales, elementos simbólicos y una eficiente capacidad narrativa, que aporta comentarios y genera la impresión de la develación de lo íntimo. También puede notarse que, pese a que las figuras tienen articulación limitada, los signos gestuales y corporales tienen un lugar destacado, pues el gesto de cubrirse los ojos manifiesta el tipo de relación que el personaje mantiene con las circunstancias que lo rodean. De modo que el relato no se limita a mostrar lo exterior, se focaliza en la subjetividad, manifestando una postura antibélica de quien no participa en la lucha, pero está rodeado por ella.

En un plano de conjunto aparece la figura femenina en primer plano, sosteniendo flores secas, y la masculina en segundo plano con una pequeña canasta. Las figuras se aproximan y giran en una ronda, acompañados por las flores, mientras en el fondo se ven gotas de agua caer, lo que es observado por la muñeca-secreter.

Debemos destacar que aquí se trata de una narración maravillosa en la que se inserta un acontecimiento histórico, pues la acción principal corresponde a la estructura de los cuentos analizados por Propp, aunque con variantes leves (la situación inicial queda sobreentendida): un tiempo de paz, en el que se produce un acontecimiento que altera la situación, cuando se clausura la iglesia y los protagonistas se separan de su hogar, mediante las «concentraciones». La prohibición y la orden de luchar (esfera de acción del mandatario) corresponden al clero y al gobierno. La participación en la lucha y el triunfo en combate constituirían la prueba y tarea a que serían sometidos los protagonistas, que no participan en el conflicto y no pasan la prueba ni cumplen la tarea, pues uno de ellos se cubre los ojos para no ver la batalla y ninguno toma las armas. En cambio, esta pareja se conoce, baila una ronda. No matan, tendrán hijos (responden a otro mandato, implícito) y repiten, en otro contexto, las mismas acciones que realizaron los primeros abuelos: formar una pareja.

El conflicto cristero es el escenario donde el personaje masculino manifiesta su antibelicismo y en el que tiene lugar la historia de esta pareja.

En el corto se ofrece ahora un plano detalle de las goteras de la habitación y entonces la muñeca-secreter se desplaza hacia adelante, para evitar que el agua siga cayendo sobre el teatrino. En el nivel de la banda sonora se escuchan sonidos del arrastre del mueble, mientras se muestra su desplazamiento. Aquí 
se conectan los hechos del relato marco con los del relato enmarcado. Kayser observa la existencia de relatos en los que se mantiene una relación estrecha entre el marco y el relato enmarcado ${ }^{43}$, como aquí. También nota que la narración enmarcada refiere a hechos pasados, respecto al relato-marco, y que las relaciones entre esas dos temporalidades pueden ofrecer variantes. En el cortometraje, al mismo tiempo que las temporalidades de los dos relatos enmarcados de los abuelos se señalan como posteriores, se manifiestan también como copresentes al marco, pues mediante el recurso de la escenificación del pasado, ese pasado se actualiza en el «ahora». Además, los acontecimientos que se verifican en el contexto del relato marco afectan a los acontecimientos del relato enmarcado, pues el agua gotea en el contexto marco, pero cae en el contexto del relato enmarcado. Esto violenta los límites entre los dos espacios y tiempos, ofreciendo una representación en la que pasado y presente son contemporáneos. Además, la muñeca-secreter es testigo presencial del pasado, al mismo tiempo que es protagonista en el «presente», participa de ambas temporalidades, como ser omnipresente cuyas acciones afectan a los hechos del pasado (evita que el agua caiga en el espacio en que se ubica la historia de los abuelos). La irrupción del presente en la escenificación del pasado no es permanente en el cortometraje y hay momentos en los que ambas temporalidades están separadas, por lo que podemos decir que la configuración del espacio-tiempo es compleja, aunque no corresponde a una representación lineal y convencional de lo temporal, sino a una concepción del tiempo en la que el presente puede incidir en el pasado, lo cual también ocurre en los relatos míticos y maravillosos.

La banda sonora no solo sirve para dar unidad e integrar secuencias distintas que involucran temporalidades diferentes, también anuncia las imágenes que veremos. Esto ocurre enseguida, cuando se ofrece un gran plano de la cabeza de la muñeca-secreter mientras se escucha el cacarear de una gallina (sonido sin relación con la imagen), previo a la vista en picado del personaje que representa a la abuela materna joven, próxima a las figuritas de una gallina y sus polluelos. Enseguida vemos salir un pequeño muñeco de tela azul desde debajo de la falda de la figura femenina (representando un parto), por lo que

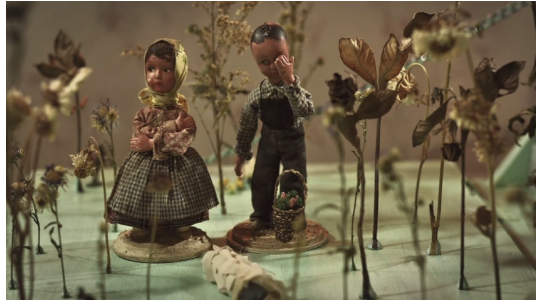

Fotograma de La casa triste. podemos notar que el sistema de analogías simbólicas (aquí gallina-madre) se mantiene a lo largo del filme y que las prospecciones sirven para ilustrar una concepción de lo temporal como un suceder que puede ser anunciado por indicios que adelantan lo que posteriormente ocurrirá o se representará.

En un plano completo se mostrarán los personajes de los abuelos, próximos al pequeño muñeco de tela azul que ha salido de la falda de la abuela; el

[43] Wolfgang Kayser, Interpretación y análisis de la obra literaria, p. 262. 
[44] David Roas, Tras los límites de lo real. Una definición de lo fantástico, p. 10.

[45] Tzvetan Todorov, Introducción a la literatura fantástica.

[46] Vladimir Propp, Morfología del cuento, p. 116.

[47] Propp define la función como la «acción de un personaje definida desde el punto de vista de su significación en el desarrollo de la intriga». Vladimir Propp, Morfología del cuento, p. 32. muñeco es envuelto por una tela blanca que se aproxima autónoma, mientras la figura femenina mantiene los brazos cruzados y la masculina se tapa con una mano el rostro, gestos que comentan el acontecimiento.

A esta escena sigue el plano detalle de una fotografía en la que se observa una pareja con ropas de trabajo. Sobre los personajes de la fotografía, veremos tachaduras moverse sobre sus pechos y sus rostros (expresando agitación). Luego las tachaduras desaparecen.

$\mathrm{Al}$ mostrar a las figuras que interpretan el papel de los abuelos y luego la fotografía, se vuelve a hacer uso de la analogía y de un recurso que busca la «confirmación» de la veracidad de lo narrado, pero también se indica la ficcionalidad de la representación escenificada por los objetos, contrastados con los personajes fotografiados. Este contraste no plantea un conflicto entre lo que se supone real y lo reconocido como ficticio, alejando el relato de lo fantástico para adscribirlo a lo maravilloso, de acuerdo con lo que Roas ${ }^{44}$ y Todorov ${ }^{45}$ señalan al respecto.

En el siguiente plano se verá en detalle un cajón que se abre y cómo el pequeño muñequito envuelto se introduce en él. El cajón se cierra. Se mostrará la figura que representa a la abuela y veremos salir dos pequeñas muñecas-bebé de debajo de su falda (nuevo nacimiento). En el nivel de la banda sonora se escuchará el llanto de pequeños. Se abrirá otro cajón en cuyo interior se enciende una caja musical, cuya música acompañará la toma de las dos pequeñas sentadas frente a frente, jugando. En seguida se introduce otro plano detalle del libro en que puede leerse: «Dicen que si se viene de una guerra, alguien de la familia paga los platos rotos y enferma». Podemos observar que el escrito adelanta lo que ocurrirá, al mismo tiempo que se ofrecen las razones de la enfermedad posterior de una de las dos pequeñas.

La forma en que se interpreta en el escrito la enfermedad orienta la significación de los acontecimientos, presentados aquí como acciones de un relato «maravilloso» ${ }^{46}$, pues el narrador señala que la enfermedad de la pequeña es el castigo por una falta cometida (el abandono de la guerra) por quienes son identificados así como trasgresores y falsos héroes en la guerra. Podemos decir, siguiendo la interpretación que el propio cortometraje expresa, que la necesidad de la pareja es distinta a la del clero (mandatario) ${ }^{47}$ : combatir en la guerra contra el gobierno, que es presentado como agresor en el filme. Cuando la pareja no combate, recibe un castigo: la enfermedad de una de sus hijas. La mitificación e identificación con una deidad de que es objeto el mandatario (el clero) se hace evidente por ser capaz de castigar a los desertores con la enfermedad de un descendiente. La enfermedad de la hija es representada al mostrar a la pequeña muñeca cubierta por una sustancia verde y la imagen de una niña en una fotografía, con una cara que se erosiona y al lado de la cual se escribe la palabra «loca». También se expresarán las consecuencias de este acontecimiento mediante los garabatos animados sobre la fotografía de la pareja de abuelos que, mediante intervenciones sobre la imagen, lloran y muestran sobre su cuerpo líneas animadas que indican agitación mientras se 
escucha el mugir lastimero de un vacuno.

El castigo no se limitará a la enfermedad de la pequeña, pues el texto indica que lo narrado ocurrirá más de una vez: «Entonces sucedió por primera vez, el abuelo enfermó de tristeza, de cáncer», lo que constituye otra prospección. La fotografía de la pareja de trabajadores muestra ahora a la figura masculina cubierta por tachaduras. Veremos la parte posterior de un pequeño camión del que sale una maraña de pelo que cae, y la puerta trasera del camión se cierra, mostrando una flor seca adherida para indicar que el vehículo traslada a un difunto. Posteriormente se ve a la figura femenina en compañía de las pequeñas, con la cabeza inclinada. En otra toma, la maraña de pelo se introduce en un cajón del secreter, en el que hay tela y mechones de pelo. El cajón se cierra. La situación descrita señala la muerte del abuelo.

En el mismo escenario del campo, en una toma general, una pequeña muñeca de trapo adulta juega con la muñeca-bebe que ha representado a la hija enferma. En un plano posterior se ve la figura que representa a la abuela sosteniendo las hojas que penden de un tallo. Los objetos escenificarán ahora el relato del destino de la hija sana que ha crecido, representada ahora por una muñeca de trapo que deja a su madre y hermana enferma cuando parte en un vehículo (otro juguete), dejando el campo.

Si bien las historias de los abuelos han sido narradas dando por sobreentendidas diversas acciones, este otro episodio ofrecerá un mayor número de acciones explícitas y, aunque involucrará siete personajes principales, manifiesta una redistribución de las «esferas de acción», conjunto de acciones que corresponden a cada uno de los siete roles identificados como característicos del relato maravilloso por Propp ${ }^{48}$.

En la historia de la hermana sana, último relato enmarcado, se puede observar lo que Propp denomina alejamiento reforzado (muerte del padre, unida al alejamiento del hogar), comentado en el filme por la vista panorámica de un cielo densamente nublado. En su alejamiento, la protagonista conocerá a un muñeco de tela, a quien le expresa su deseo de formar con él una familia: cuando le muestra un dibujo con niños y él enlaza su mano a la de ella (aceptando). Este personaje se presenta así como auxiliar, que ayudará a satisfacer la necesidad de la protagonista, la misma que tenían los abuelos: una familia, pero el narrador caracteriza esta historia de modo diferenciado, cuando en el libro se lee «1951. Esa fue la primera historia de amor».

Hasta ahora hemos identificado la recuperación de diversas funciones propias de los relatos maravillosos, pero también hemos identificado diferencias. Notaremos que, en los cuentos analizados por Propp, el matrimonio se presenta como premio a la realización de la tarea; mientras que, en el filme, el matrimonio constituye el medio para satisfacer la necesidad de los personajes de tener una familia. En el caso del relato de la hija sana, el matrimonio es el medio para satisfacer su necesidad de tener hijos y el marido será su auxiliar, cumpliendo también con el rol de donante aunque la historia se caracterice como primera historia de amor.

[48] Vladimir Propp, Morfología del cuento, pp. 91-92. 
La escena festiva de esta otra boda reúne a los personajes sobrevivientes de las historias previas. A la celebración seguirá un plano detalle del libro abierto en el que veremos un dibujo a lápiz de dos aves con rostros humanos y, en la página contigua, las palabras «Vida, muerte, tristeza, alegría, tristeza, muerte», que ofrecen un condensado de las experiencias de la pareja, representada en el dibujo como dos aves humanizadas que, como la muñeca-secreter, participan de una mezcla de rasgos de dos seres distintos.

Mediante una serie de imágenes alegórico-simbólicas (una mariposa nocturna, un cielo nublado, la caída y daño de personajes-objetos, tachaduras sobre las fotografías, la toma en detalle de palabras escritas en el libro, cajas y cajones que se cierran), se narrará la muerte de los tres abuelos y la hermana enferma. En las imágenes se subraya la modalidad expresiva y simbólico-metafórica sobre la modalidad narrativa de las imágenes. Para exponer el estado emocional de la muñeca de trapo y de la muñeca-secreter se emplean tachaduras que cubren la fotografía de una novia y llegan a cubrir también la superficie y el rostro de la muñeca-secreter en su totalidad. En el escrito se indica la improbabilidad de que la muñeca de trapo tenga hijos. Veremos luego su enfrentamiento con la enfermedad (nuevo agresor), representada como una especie de extraña araña de tela y cabellos, con rostros fotográficos cambiantes (los de los personajes muertos). Este combate simbólico confronta la voluntad de la protagonista de tener hijos contra la muerte y señala la tarea difícil que ella misma se ha impuesto: ser madre, lo que es también su carencia por satisfacer.

Propp nota que no todos los cuentos tienen el mismo número de funciones, sino un núcleo regular ${ }^{49}$, y que, cuando un falso héroe no cumple una tarea (en este caso el abuelo materno), se introduce otro héroe (aquí, su hija), lo cual se verifica en el cortometraje.

El desenlace de la historia es precedido por el cese de la lluvia que ha invadido el interior, mojando a la araña monstruosa, lavando las «tachaduras» que figuraban sobre la muñeca-

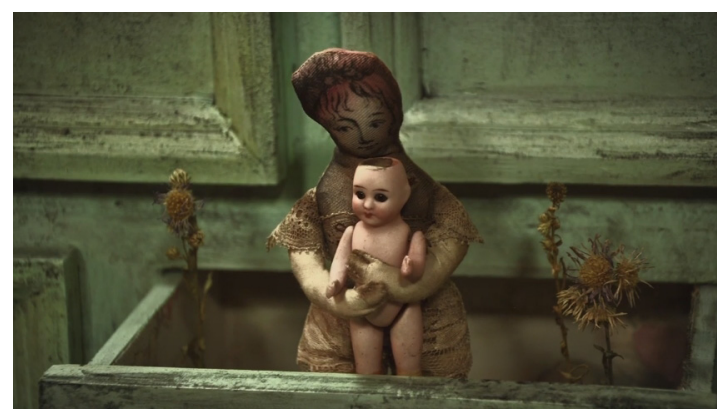

Fotograma de La casa triste. secreter, el piso, los objetos y muros. Esa lluvia funciona como auxiliar y cesa poco a poco, mientras se escucha el canto de una voz infantil que antecede a la toma en plano americano de la muñeca de trapo sosteniendo en sus brazos a otra pequeña muñecabebé (con una cabeza similar a la de la muñeca-secreter) y saliendo parcialmente de un cajón por el que se asoman flores. A esta toma, le sigue otra que muestra de

[49] Vladimir Propp, Morfología del cuento, p. 115. espaldas, en encuadre completo, al muñeco de tela construyendo edificaciones. Imágenes de felicidad y maternidad, denotada claramente por las fotografías de 
una mujer que carga un bebé y de una niña que carga su muñeca que se muestran dentro de un cajón abierto. Sigue una toma panorámica del cielo que se despeja y que permite saber que la carencia ha sido satisfecha, reconociendo también a la heroína del relato: la madre.

Propp considera las motivaciones y atributos de los personajes: su análisis permitiría, para él, «una interpretación científica del cuento», pues en los atributos se manifiesta «la influencia de la realidad histórica» $5^{\circ}$, lo que los hace también elementos sumamente variables ${ }^{51}$. Nosotros los consideramos en la lectura analítica del filme.

\section{Resultados: lectura y conclusiones}

En La casa triste, el relato marco y los enmarcados corresponden a relatos maravillosos, y son los acontecimientos del relato marco los que afectan a los de los relatos enmarcados, difiriendo de la modalidad identificada por Roas a la que hemos hecho referencia al principio de este trabajo. Aquí, los elementos realistas son recursos para generar verosimilitud: entre ellos, se encuentran la inclusión de fotografías, recreación de ambientes y acontecimientos, un relato escrito en primera persona, el descubrimiento de documentos y el uso de ciertos elementos retóricos de la crónica, la inclusión de un hecho histórico y su reinterpretación escrita y escénica. Los elementos «maravillosos» involucran no solo la estructura de relatos maravillosos, también la animación y humanización de objetos, dibujos que contribuyen a la creación de personajes ficticios híbridos y alegórico-simbólicos, así como el uso de tropos y elementos retórico-poéticos, la inclusión de acontecimientos que vulneran la lógica y normas realistas y la interpretación de hechos vinculados a acontecimientos históricos como funciones de un relato mítico-maravilloso, tal como lo define Propp ${ }^{52}$.

En el filme, se presenta el relato maravilloso como una verdad guardada en la memoria familiar, lo cual posibilita una reinterpretación de lo histórico al mismo tiempo que confiere autoridad al narrador como guardián y portador de esa «verdad» (que es realmente un relato maravilloso). La inclusión de elementos realistas e históricos en una narración mítico-maravillosa es distinta aquí de la presencia de lo verosímil en lo fantástico y de lo histórico en lo mítico, propias del realismo mágico ${ }^{53}$.

Otro fenómeno que se destaca es la recurrencia en el uso de diadas, manifiesta en las parejas protagonistas, los personajes que participan de una doble naturaleza (el secreter-muñeca, el alfiletero-muñeca, las aves con rostros humanos), las hermanas gemelas, el relato dentro del relato, las oposiciones entre la vida y la muerte, las figuras del héroe y el falso héroe y del héroe y el agresor, los bandos opuestos en un combate. Elementos que corresponden a una estructura del doble, que ofrece variadas modalidades (dobles antagónicos, complementarios, idénticos, simétricos, etc.), incluyendo la del ser híbri-
[50] Vladimir Propp, Morfología del cuento, pp. 85, 101.

[51] Vladimir Propp, Edipo a la luz del folklore (Madrid, Fundamentos, 1982), Las raíces históricas del cuento (Madrid, Fundamentos, 1974) y Folclore y realidad (Madrid, Alianza Editorial, 2007).

[52] Respecto a la identificación del cuento mítico con el tipo de relatos analizados por Propp, él señala al respecto: «la palabra maravilloso debe ser reemplazada por otro término. Es muy difícil hallar uno y por eso dejamos provisionalmente [...] su antigua denominación [...]. Si se define a estos cuentos desde un punto de vista histórico merecen su antiguo nombre en la actualidad abandonado, de cuentos míticos». Vladimir Propp, Morfología del cuento, p. 116.

[53] «En el realismo mágico [...] el sentido de irrealidad se alcanza a través del asombro ante la realidad, sin destruirla. En vez de presentar la magia como si fuera real, presenta la realidad como si fuera mágica: personajes, cosas, acontecimientos, son reconocibles y razonables; lo que el escritor se propone es provocar sentimientos de extrañeza y se abstiene de aclaraciones racionales». Gloria Bautista, «El realismo mágico: historiografía y características» (Verba hispánica: anuario del Departamento de Lengua y Literatura Españolas de la Facultad de Filosofía y Letras de la Universidad de Ljubljana, $\left.{ }^{\circ} 1,1991\right)$, p. 21. 
[54] La herencia prehispánica y «el trauma de la Conquista» en Malapata (Ulises Guzmán, 2000) y en Catrina, Posada y la gran piedra (José Ángel García Moreno, 2001), la recuperación de la tradición indígena en trabajos de Dominique Jornard, como Cuentos purépechas (1990), la migración en Crónicas de Manhatitlán (Felipe Galindo, 200o) y revisiones históricas en La flauta de Bartolo o la invención de la música (Paul Leduc, 1997). Ver La Redacción, «El repunte del cine mexicano de animación».

[55] Han sido atendidos por estudiosos como Tzvetan Todorov en La conquista de América. El problema del otro (México, Siglo XXI Editores, 1982), Ilán Stavan en La pluma y la máscara (México, Fondo de Cultura Económica, 1993) y Edmond Cros en «La puesta en escena de la diferencia en Terra Nostra de Carlos Fuentes" (Trama y fondo: revista de cultura, $\left.\mathrm{n}^{\circ} .20,2006\right)$, pp. 7-13, «Foundations for a Sociocriticism. Methodological Presuppositions and Their Applications to La región más transparente by Carlos Fuentes», en Eduardo Forastieri-Braschi, Gerald Guinnes y Humberto

López Morales (eds.) On the Text and the Context: Methodological Approaches to the Contexts of Literature (San Juan Puerto Rico, Editorial Universitaria, 1980), pp. 75-94, y en Literatura, ideologia y sociedad (Madrid, Gredos, 1986). Fenómenos no solo presentes en textos del pasado; también presentes, según los últimos dos autores, en diversas obras de escritores mexicanos del siglo XX de gran influencia cultural, como Octavio Paz y Carlos Fuentes, unidos a interpretaciones psicoanalíticas de la identidad cultural nacional.

[56] Juan Manuel Rodríguez Penagos, «Juan Rulfo y el ensueño del tiempo» (Mal-Estar e Subjetividade, vol. III, no 1, marzo de 2003), pp. 130-150; Roberto Cantú, «De nuevo el arte de Juan Rulfo: Pedro Páramo reestructura(n)do» (Cuadernos Hispanoamericanos, ${ }^{\circ} 4^{2-423}$, 1985), pp. 305-354.

[57] Sergio Guillermo Figueroa Buenrostro, «Algunos aspectos narrativos y temáticos en Las tierras flacas» (en Lenguaje y cultura en la narrativa de Agustín Yáñez, Guadalajara, Universidad de Guadalajara, 2018), pp. 129-142.

[58] Stanislas Mbassi, Aproximación sociocrítica a Los de debajo de Mariano Azuela (Tesis Doctoral inédita, Granada, Universidad de Granada, 2013). rias y artísticas, como el acrílico La fusión de dos culturas (1963), de Jorge las guerras cristeras, la importancia que adquiere la familia tradicional, el do, compuesto o integrado por dos entidades distintas y que figura en relación con la recuperación de algunos acontecimientos históricos.

En el cine de animación mexicano no son pocas las producciones que han incluido temáticas o asuntos históricos, abordados desde perspectivas variadas ${ }^{54}$, ni son pocas las obras culturales en el país en las que la identidad del ser se ha representado como estructurada por una dualidad y una hibridación. Estos fenómenos han sido analizados en relación con la pervivencia de estructuras ideológicas asociadas al tema de la Conquista y del mestizaje ${ }^{55}$ $\mathrm{y}$, aunque localizables en otras tradiciones culturales, han desempeñado un papel de enorme importancia en las interpretaciones de la identidad cultural mexicana a lo largo del tiempo, pues es ampliamente conocida la concepción dualista del ser mexicano que está contenida en la obra de Octavio Paz El laberinto de la soledad (1950) y que figura también en diversas obras literaGonzález Camarena, el mural Cortés y la Malinche (1926), de José Clemente Orozco, y las obras literarias de Juan Rulfo ${ }^{56}$, Agustín Yáñez ${ }^{57}$, Mariano Azue$l^{58} \mathrm{y}$ otros destacados escritores jaliscienses.

El siguiente fenómeno a considerar es la presencia de un conjunto de elementos religiosos que no solo se manifiestan en los hechos históricos recuperados. También están involucrados en valores y creencias implicados en el filme, en las palabras escritas, en acciones como negarse a matar o creer en el castigo divino por las faltas cometidas; incluso en el encuadre que se adopta en algunas tomas al observar a los personajes, la forma como se representan las tumbas, la perspectiva frente a los hechos del gobierno durante sufrimiento como condición previa al gozo y la correlación que se establece entre el agua y la salvación (como alusión velada al símbolo religioso del bautismo).

A lo anterior se añade la humanización de las cosas al ser animadas e identificadas con personas en fotografías, miembros de una historia familiar y personajes de un hecho histórico (la guerra cristera), pues la humanización constituye una sistemática recurrente en el filme, que se hace manifiesta también en su título: La casa triste. Y debemos recordar que la humanización está 
vinculada a corrientes de pensamiento humanistas de muy diverso tipo, pero que en el filme está unida a otros fenómenos indicativos de una ideología específica y que corresponde al contexto de producción del corto, cuando la orden franciscana ${ }^{59}$ tuvo y sigue teniendo un papel socio-cultural considerable, como orden fundadora de diversos asentamientos y resguardante de figuras de culto religioso significativas en la zona del centro-occidente del país.

Tanto desde la perspectiva que ofrecen Mariño como Roas, como desde la de quienes, como Todorov, distinguen claramente lo fantástico de lo maravilloso, la narración cinematográfica analizada corresponde al relato maravilloso, pese a la presencia de las referencias históricas y a recursos que buscan establecer la verosimilitud de lo narrado. No es solo debido a la técnica de animación que se emplea, sino también porque en el filme se hace uso de personajes que poseen rasgos de seres híbridos y se verifica la humanización de los objetos, el uso de recursos alegórico-simbólicos y la inclusión de acciones y hechos sobrenaturales o paranormales. El dominio del relato míticomaravilloso al relatar una historia familiar y colectiva es demostrable también porque en el cortometraje figuran explícitamente numerosas funciones definidas por Propp, aunque otras quedan implícitas y se redistribuyen las esferas de acción por él identificadas. Sin embargo, muchas de esas variantes fueron también consideradas por el investigador ruso, quien, además, destaca que: «... se deben definir la funciones sin tener en cuenta la identidad de aquél que las realiza [...] ni la forma en que se rellenan» ${ }^{60}$. Propp admite que la cadena de funciones está sujeta a transformaciones ${ }^{61}$, que son más importantes aquí por tratarse de un filme contemporáneo que tiene autoría y no de un relato de tradición oral.

Los cambios entre el esquema analizado por Propp y los que ofrece el filme son significativos, porque podemos notar que la carencia es aquí tener una familia, tener hijos. La obra da prioridad a las figuras femeninas, una de la cuales se presenta como protagonista-heroica (la madre), otra como narradora ficcionalizada (muñeca-mueble) y otras como personajes secundarios: primera heroína (primera abuela), falsa heroína que no combate, pero da vida (segunda abuela), víctima (hermana enferma) y personaje buscado (hija). Las figuras masculinas ofrecen una diversidad de roles que van desde la figura del héroe (primer abuelo), falso héroe que no combate y da vida (segundo abuelo) hasta el auxiliar-donante (padre). Al mismo tiempo, no es menos importante que se representen roles de género extremadamente convencionales, pues las figuras femeninas están asociadas a labores como la costura (muñeca-alfiletero), labores del campo, pero sobre todo al papel de esposa y madre. Además, los agresores son el gobierno opuesto al clero, así como una figura alegórica-simbólica que representa la muerte. Uno de los auxiliares desciende, literalmente, del cielo (la lluvia), mientras que las funciones de los mandatarios las desempeñan varios personajes explícitos (el clero y el gobierno) y otro tácito (un mandatario al que responde el rechazo a matar y la necesidad de la multiplicación de la especie). El matrimonio no
[59] Aunque el humanismo franciscano se orientó a la educación, puesta en práctica del pensamiento utópico y rescate de las humanidades, se va a manifestar también en la importancia otorgada a la estructura familiar, al concepto de su fundador que consideraba hermanos y humanizaba a todos los seres en su Cantico delle creature. Antonio José Echeverry Pérez, «Franciscanos, tras ideales utópicos» (Historia y Espacio, no 28, vol. 3, 1007), pp. 65-91.

[6o] Vladimir Propp, Morfología del cuento, p. 75 .

[61] Vladimir Propp, Morfología del cuento, pp. 115-116. 
[62] Hasta 1988, México contaba con cuatro beatos católicos. En el periodo se sumarían cincuenta más, todos cristeros. A esto se añade que el presidente en funciones expresara públicamente la supuesta participación de su padre como correo cristero en el periódico mexicano El Universal, el 7 de febrero de 2009. Damián López, «La guerra cristera (México, 19261929). Una aproximación historiográfica», p. 37.

[63] «[...] a partir la segunda mitad de los años ochenta, la iglesia católica emprende una pastoral electoral [...]. Esta acción, donde la iglesia asumió jugar un papel decisivo sobre el rumbo político del país, va desarrollando una teología electoral, mediante la cual insta a los católicos a participar en las elecciones, pues no votar es un pecado cristiano. La concientización por la democracia va adquiriendo un tinte teológico, pues no se instruye sobre cualquier voto libre, sino que busca modelar el voto del cristiano favoreciendo a aquellos partidos y políticos que concuerden con los valores de la iglesia católica». Renée de la Torre, «La Iglesia Católica en el México contemporáneo» (L'Ordinaire des Amériques, $\mathrm{n}^{\circ} 210,2008$ ), pp. 27-46. Disponible en: $<$ http://journals.openedition. org/orda/2616> (12/08/2017). es la recompensa, sino el medio para lograr una familia, hijos, que son aquí la necesidad principal. Estos elementos son indicativos de la ideología vehiculada en el filme.

Otros elementos que han sido ampliamente estudiados en obras mexicanas y que figuran en el filme son las representaciones de la muerte como figura alegórica y las representaciones de una temporalidad que no corresponde a las concepciones lógico-lineales del devenir. Entre las representaciones de la Muerte se encuentra la «Catrina», que José Guadalupe Posada retoma para uno de sus grabados y que reaparece en un mural de Diego Rivera, Sueño de una tarde dominical en la Alameda Central. El tema, considerado representativo de lo popular mexicano, figura incluso en la obra inacabada iQue viva México! (1931), de Sergei Eisenstein, y reaparece en filmes como El ahijado de la muerte (Norman Foster, 1946), La muerte enamorada (Ernesto Cortázar, 1951), Macario (Roberto Gavaldón, 1960), e incluye el cine de animación: iHasta los huesos! (2001), de René Castillo, y La leyenda de la Nahuala (2007), de Ricardo Arnaiz. Sobre el tiempo mítico en la cultura mexicana, se pueden referir Tiempo mexicano (1978) y Nuevo Tiempo Mexicano (1995), de Carlos Fuentes, así como La filosofía náhuatl (1956,) de Miguel León Portilla, y el trabajo de Jean-Marie Gustave Le Clézio, El sueño mexicano o el pensamiento interrumpido (2012), obras que ofrecen destacadas aportaciones sobre el tema y su relación con la configuración popular de una identidad nacional, promovida a lo largo del siglo XX por el partido político gobernante.

En el cortometraje, la mediatización de recuerdos colectivos diluye la diferencia entre el recuerdo colectivo subjetivado de un hecho histórico y la interpretación del hecho como acontecimiento mítico-maravilloso que se presenta integrado en el relato de la memoria familiar, relato este cuya veracidad se busca validar mediante estrategias narrativas específicas.

La familia, estructurada de modo tradicional, es mitificada al representarla como protagonista del relato maravilloso en el que la principal necesidad es la pervivencia de la especie: se destaca la madre como figura heroica, la muerte y su antesala (la enfermedad) como agresores y el castigo por una falta que solo logra superar la figura femenina sufriente cuya única aspiración y necesidad es ser madre.

Las referencias históricas del filme, al ser ubicadas en el contexto temporal y geográfico de producción del cortometraje, permiten identificar otros elementos y fenómenos sociales nacionales que dejan huellas en el filme, ya que con el ascenso del PAN (Partido Acción Nacional) a la presidencia del país, se suscitó un movimiento de reivindicación de los cristeros y el tema volvió a ser asunto frecuente en el periodo, con matices específicos que adoptaban una perspectiva religiosa ${ }^{62}$, fortalecida en el país, al encontrarse en el poder grupos conservadores ${ }^{63}$.

Renée de la Torre ha observado que desde finales del siglo XX tuvo lugar en México, por parte del clero, «una centralización del poder eclesial, un acti- 
vismo en la esfera de la política electoral, se fortalecieron las posiciones conservadoras en torno a temas de familia, sexualidad y el derecho a la vida [...]» ${ }^{64}$. Sobre el último punto, la investigadora destacará la influencia que el papado ejerció con « [...] su cruzada en contra de la 'cultura de la muerte'» ${ }^{65}$. La difusión de esta ideología desde el Estado y mediante los aparatos ideológicos de estado volvería nuevamente asunto de controversias álgidas temas como el aborto, el uso de anticonceptivos, los matrimonios homosexuales e, incluso, la emancipación femenina, poniendo en relevancia la familia tradicional y la protección a los hijos, incluso los no nacidos.

Pese a que los elementos ideológicos identificados guardan una relación estrecha con el contexto específico de producción del filme, no podemos ignorar que, en el cortometraje estudiado, se ofrece una representación específica de un hecho que ha tenido representaciones escritas constantes a lo largo del tiempo, principalmente en textos históricos y literarios, que han establecido un canon de construcciones. A su vez, el filme aporta un esquema para futuras representaciones de los acontecimientos históricos, por lo que no podemos ignorar su papel en la construcción de representaciones sociales e ideológicas que se difunden a los públicos a través de la cinematografía.

Sobre esto último, Julián Woodside ha estudiado la forma en que el cine de animación ha desempeñado un papel significativo en la «construcción de narrativas oficiales en México» ${ }^{66}$. Fenómeno que se explica, en parte, por las características concretas que en el país tiene actualmente la producción fílmica y respecto a la cual se ha señalado: «La composición del financiamiento de las producciones ha cambiado significativamente: mientras que a principios de la década de 1990 menos de 20\% eran financiadas con fondos públicos, en 2008 estas representan $80 \%$ del total» ${ }^{67}$. Datos significativos si consideramos la incidencia que las ideologías del Estado pueden tener de manera directa o indirecta en las producciones cinematográficas ${ }^{68}$.

Estamos de acuerdo con Burguera cuando señala que la proliferación de este tipo de filmes responde a «una reacción frente al pensamiento científico» ${ }^{69}$, pues los relatos maravillosos permiten explorar inquietudes que no encuentran expresión en el pensamiento racionalista actual, pero el estudio a partir de las aportaciones metodológicas adoptadas nos permite identificar una variación estructural en las modalidades que pueden ofrecer los relatos enmarcados y la destacada vinculación del filme con el entorno socio-histórico y cultural de su producción fílmica, así como sus dominantes ideológicas y su papel como medio de difusión de ideologías oficiales, que vehicula a través de la ficción y la reinterpretación de los acontecimientos históricos.
[64] Renée de la Torre, «La Iglesia Católica en el México contemporáneo».

[65] Renée de la Torre, «La Iglesia Católica en el México contemporáneo».

[66] Julián Woodside, «Cine y memoria cultural: la ilusión del multiculturalismo a partir de dos películas mexicanas de animación», pp. 65-84.

[67] Jorge Mario Martínez Piva, Ramón Padilla Pérez, Claudia Schatan Pérez y Verónica Vega Montoya, La industria cinematográfica en México y su participación en la cadena global de valor (México, CEPAL, 2010), pp. 29-30.

[68] Sobre el tema se puede consultar: Diego Zavala Scherer, «Mitificación/desmitificación en Suertes, humores y pequeñas historias de la Independencia y la Revolución (2010), proyecto de animación industrial en Jalisco, México", (El ojo que pien$\left.s a, \mathrm{n}^{\circ} 3,2011\right), \mathrm{p} .15$.

[69] Juan José Burguera, Donación simbólica, donación siniestra: aportaciones sobre el cine de fantasía y el cine fantástico, p. 25. 


\section{FILMOGRAFÍA}

El gabinete de Jan Svankmajer (The Cabinet of Jan Svankmajer, Stephen y Timothy Quay, 1984).

Jabberwocky (Jan Švankmajer, 1971)

La calle de los cocodrilos (Street of Cocodriles, Stephen y Timothy Quay, 1986)

La casa triste (Sofia Carrillo, 2013)

Renaissance (Walerian Borowczyk, 1964)

\section{BIBLIOGRAFÍA}

Aumont, Jacques, Estética del cine. Espacio filmico, montaje, narración, lenguaje (Buenos Aires-Barcelona-México, Paidós, 2008).

AurrecoecheA, Juan Manuel, El episodio perdido. Historia del cine mexicano de animación (México, Cineteca Nacional, 2004).

Aumont, Jacques y Marie, Michel, Análisis del film. (Barcelona, Paidós, 1990).

BAUTISTA, Gloria, «El realismo mágico: historiografía y características» (Verba hispánica: anuario del Departamento de Lengua y Literatura Españolas de la Facultad de Filosofía y Letras de la Universidad de Ljubljana, $\mathrm{n}^{0} 1,1991$ ), pp. 19-26.

Bettelheim, Bruno, Psicoanálisis de los cuentos de hadas (Barcelona, Grijalbo-Mondadori, 1994).

Bhartiya, Abhilasha, «Stop Motion. A Study on the Most Usefull Technique of Experimental Animation» (Shrinkhala, vol., II, febrero de 2015), pp. 1-8. Disponible en: <http://www.socialresearchfoundation.com/upoadreserchpapers/3/43/15052105 37511st\%20abhilasha\%2omalviya.pdf > (14/08/2017).

Burguera Rozado, José, Donación simbólica, donación siniestra: aportaciones sobre el cine de fantasía y el cine fantástico (Tesis Doctoral inédita, Madrid, Universidad Complutense, 2015).

CANTú, Roberto, «De nuevo el arte de Juan Rulfo: Pedro Páramo reestructura(n)do» (Cuadernos Hispanoamericanos, $\mathrm{n}^{0}$ 42-423, 1985), pp. 305-354.

CAStro, Karina y SÁnchez, José, Dibujos animados y animación (Quito, CIESPAL, 1999).

Cros, Edmond, «La puesta en escena de la diferencia en Terra Nostra de Carlos Fuentes» (Trama y fondo: revista de cultura, $\mathrm{n}^{\circ} .20,2006$ ), pp. 7-13.

-, «Foundations for a Sociocriticism. Methodological Presuppositions and Their Applications to La región más transparente by Carlos Fuentes», en Eduardo ForastieriBraschi, Gerald Guinnes y Humberto López Morales (eds.), On Text and Context. Methodological Approaches to the Contexts of Literature (San Juan Puerto Rico, Editorial Universitaria, 1980), pp.75-94.

-, Literatura, ideología y sociedad (Madrid, Gredos, 1986).

Echeverry Pérez, Antonio José, «Franciscanos, tras ideales utópicos» (Historia y Espacio, $\mathrm{n}^{0} 28$, vol. 3, 1007), pp. 65-91.

Figueroa Buenrostro, Sergio Guillermo, «Algunos aspectos narrativos y temáticos en Las tierras flacas», en Lenguaje y cultura en la narrativa de Agustín Yáñez (Guadalajara, Universidad de Guadalajara, 2018), pp. 129-142.

GENETte, Gérard, Figuras III (Barcelona, Lumen, 1989). 
González Requena, Jesús, Clásico, manierista, postclásico. Los modos del relato en el cine de Hollywood (Valladolid, Castilla Ediciones, 2007).

KAYSER, Wolfgang, Interpretación y análisis de la obra literaria (Madrid, Gredos, 1992).

LA REDACCIÓN, «El repunte del cine mexicano de animación» («Cultura y Espectáculos», Proceso, 29 de mayo de 2002). Disponible en: <http://www.proceso.com. $\mathrm{mx} / 242212 /$ reportaje-el-repunte-del-cine-mexicano-de-animacion> (2/o8/2017).

LÉvi-Strauss, Claude, Mito y Significado (Buenos Aires, Alianza Editorial, 1986).

LÓPEZ, Damián, «La guerra cristera (México, 1926-1929). Una aproximación historiográfica» (Historiografias, $\mathrm{n}^{\mathrm{0}} 1$, 2011), pp. 35-52.

LuCKÁs, Georg, «Das Problem des untragischen Dramas» (Die Schaubühne, nº 7, 1911), pp. 231-234

MARIÑo EsPuElas, Alicia, «Entre lo posible y lo imposible: el relato fantástico», en Teresa López Pellisa y Fernando Ángel Moreno Serrano (eds.) (Madrid, Asociación Cultural Xatafi-Universidad Carlos III de Madrid, 2009). Ensayos sobre ciencia ficción y literatura fantástica: Actas del Primer Congreso Internacional de literatura fantástica y ciencia ficción, pp. 40-54.

Martínez Piva, Jorge Mario, Padilla Pérez, Ramón, Schatan Pérez, Claudia y Vega MonтоYA, Verónica, La industria cinematográfica en México y su participación en la cadena global de valor (México, CEPAL, 2010).

Mbassi, Stanislas, Aproximación sociocrítica a Los de debajo de Mariano Azuela, (Tesis Doctoral inédita, Granada, Universidad de Granada, 2013).

Meyer, Jean, La Cristiada. (México, Siglo XXI Editores, 1973).

Navarro Herrera, Cecilia Mónica, El drama urbano en el cine animado de Carlos Carrera: análisis del cortometraje «El héroe» (Tesis de Maestría, Guadalajara, Universidad de Guadalajara, 2004).

Novel Monroy, Noemi, Literatura y cine de ciencia ficción. Perspectivas teóricas, (Tesis Doctoral inédita, Barcelona, Universitat Autònoma de Barcelona, 2008).

ROAS, David, Tras los límites de lo real. Una definición de lo fantástico (Madrid, Páginas de Espuma, 2011).

Propp, Vladimir, Morfología del cuento (Madrid, Fundamentos, 1974).

-, Las raíces históricas del cuento (Madrid, Fundamentos, 1974).

-, Edipo a la luz del folklore (Madrid, Fundamentos, 1982).

-, Folclore y realidad (Madrid, Alianza Editorial, 2007).

Rodríguez Bermúdez, Manuel, Animación: una perspectiva desde México (México, Centro Universitario de Estudios Cinematográficos de la Universidad Nacional Autónoma de México, 2007).

Rodríguez Penagos, Juan Manuel, «Juan Rulfo y el ensueño del tiempo» (Mal-Estar e Subjetividade, vol. III, no 1, marzo de 2003) pp. 130-150.

Stavan, Ilán, La pluma y la máscara (México, Fondo de Cultura Económica, 1993). Todorov, Tzvetan, Introducción a la literatura fantástica (México, Premiá, 1987).

-, La conquista de América. El problema del otro (México, Siglo XXI Editores, 1982).

Torre, Renée de la, «La Iglesia Católica en el México contemporáneo» (L'Ordinaire des Amériques, $\mathrm{n}^{0}$ 210, 2008), pp. 27-46. <http://journals.openedition.org/ orda/2616> (12/08/2017). 
VARGAS RodrígueZ, Juan Carlos, «Breve panorama del cine fantástico mexicano del nuevo milenio 2000-2014 tendencias y rutas temáticas» (Historia y espacio, $\mathrm{n}^{\circ} 46,2016$ ), pp. 223-263.

Vidal Ortega, M., Contribución de la animación cinematográfica, el desarrollo del trucaje cinematográfico y los efectos especiales en el cine contemporáneo (Tesis Doctoral inédita, Valencia, Universidad Politécnica de Valencia, 2008).

Woodside, Julián, «Cine y memoria cultural: la ilusión del multiculturalismo a partir de dos películas mexicanas de animación» (Estudios sobre las Culturas Contemporáneas, $\mathrm{n}^{\mathrm{o}} 36$, vol. XVIII, invierno de 2012), pp. 65-84. Disponible en: <http://www. redalyc.org/articulo.oa?id=31624694005> (22/06/2017).

Zavala Scherer, Diego, «Mitificación/desmitificación en Suertes, humores y pequeñas historias de la Independencia y la Revolución (2010), proyecto de animación industrial en Jalisco, México», (El ojo que piensa, $\mathrm{n}^{0} 3,2011$ ), p. 15.

Recibido: 25 de marzo de 2018

Aceptado para revisión por pares: 11 de octubre de 2018

Aceptado para publicación: 12 de febrero de 2019 
